\title{
The Examination of Environmental Design Principles in Public Institutions in the Example of the Current Landscape Design of Konya Courthouse
}

\author{
Sertaç Güngör* \\ Department of Landscape Architecture, Faculty of Agriculture, University of Selcuk, 42130 Konya, Turkey
}

\begin{tabular}{l} 
A R T I C L E I N F O \\
Research Article \\
Received 07 December 2016 \\
Accepted 15 February 2017 \\
\hline
\end{tabular}

Keywords:

Public institution

Courthouse

Landscape design

Konya

Public space

\begin{abstract}
A B S T R A C T
Public spaces are among the spaces requiring the most importance for the design in the evaluation of outdoor spaces. Public spaces are the common areas used by people of all ages, genders, and jobs. The key feature of the environmental design made in these areas is its requirement to be at the level of meeting the needs of people from all strata. Since there is not the main method for the evaluation of environmental planning of public institutions and organizations in the current literature and these areas strongly affect the texture of the city, a questionnaire study was conducted in our study with people using the courthouse and courthouse personnel to reveal the standards, criteria and the needs of users in public institutions. According to the results of the questionnaire, solution suggestions were made by revealing the positive and negative sides of landscape designs of the courthouse.
\end{abstract}

${ }^{*}$ Corresponding Author:

E-mail: sertac@ selcuk.edu.tr

\section{Introduction}

People want the environment that they live in to be developed, enhanced and become inhabitable. The aim of landscape architecture is to provide an inhabitable environment. Landscape architects have carried out studies from the past to present for the environmental conformity and objective for the design of all spaces. Meanwhile, the design studies of landscape architects should be sustainable. Features such as the scale, functionality, environmental limitation, the continuity of environmental limitation, creating a visual axis and perspective, orientation, legibility, image, etc. occurring in public outdoor spaces over time are the important characteristics emphasizing the environment and forming its identity (Sirel and Sirel, 2005).

The fact that there is a wide variety of users in the landscape design to be made around public buildings, a wide range of age and economic reasons play a restrictive role in the design. Creating perceivable and aesthetic spaces in field studies takes shape with the predictions of the designer (Turgut, 2011).

Designing urban public spaces as inhabitable spaces for the 'equal' usage by all individuals in the 'community' (society) is accepted as a requirement of urbanization (Kaplan and Öztürk, 2004).
Since public spaces created to meet various physical and social needs have social, physical, behavioral and psychological effects on the users, their planning and organization become important to provide a healthier society and more quality life (Bayram, 2007).

Public space designs that are among the most important colors of the city, in which the city and citizens take a breath and live freely and social relationships are intensified, have an important place in the urban development. Due to ever-growing socio-cultural, economic and technological conditions nowadays, the understanding, need and use of public spaces are affected by this situation (Kavak, 2010).

Modern cities put emphasis on urban aesthetic and the presence of public spaces as much as they put emphasis on consuming less energy and protecting natural sources. The time people spend in open, half-open and closed public spaces decreased and the balances of the face-toface social relationship started to disappear because of the Internet and developing technologies. The developments in the structure scale do not provide continuity even in the texture of a street. Spaces that cannot be even called urban texture in which uniform plans are used or the harmony of structures adjoining yet different from each 
other is destroyed are gradually formed. Urban design principles in addition to integrated urban planning should be identified for designing such spaces and the aesthetic and socio-cultural adaptation of new designs (Ay1k, 2011).

Conducting studies to evaluate outdoor spaces of public institutions and organizations as in all outdoor spaces has already become a requirement. Public institutions require special attention in their outdoor spaces since they have a direct influence on cities. In this context, the evaluation of the gardens of public institutions like all other spaces is important to identify both how much the gardens are close to the required conditions and their deficiencies. By this way, there is a chance to reveal both the values of gardens in their own design understandings and the comparative values that the institutions have with each other (Atabeyoğlu and Bulut, 2007a)

These functions adopted by public spaces are also the requirements of being a city. Moreover, they are features that a city should provide to its citizens and the citizens need. However, unfortunately, public spaces started to settle as channels which we use to pass through at certain times during day or areas concentrated on trade (Atabeyoğlu and Bulut, 2007b)

The frequency of use and the user groups changed with the privatization, selling and renting of the spaces in power of public and open public spaces. Green spaces were transformed into trading areas or spaces entered in with tickets under the name of a fairground, etc., which were claimed to be still public spaces and which brought new cultural interactions with themselves where old users disappeared completely from time to time. It was observed that public spaces were transformed into spaces in which economic concerns were attempted to be overcome rather than looking after public welfare (Ay1k, 2011).

Courthouses are one of the most significant civic buildings of a cityscape since they fulfil important functions in city life in Turkey. These buildings not only do assist essential missions, but they also contributes the formation of communal spaces. The courthouses in Turkey tend to be respected as national landmarks and a well-designed courthouse will definitely pay off its initial cost by improving environmental quality in cities. Similar to other big construction activities, location selection decision has an intense influence on practically all aspects of the design process of a courthouse project (Topraklı et al., 2016).

In this study, the evaluation of the garden landscape design of Konya Courthouse, which is a concrete example, is carried out in the context of the environmental design principles in public institutions.

\section{Material and Method}

The garden of Konya Courthouse building constitutes the material of the study. Konya Courthouse which is the study area is located in 37.861240 latitude and 32.544930 longitude. Konya Courthouse which is located between
Yeniceler Street and Adana-Ankara beltway is connected to Akabe neighborhood, Karatay district (Figure 1). The Courthouse building has an open space of approximately 14 thousand square meters and provides service with 9 main entrance doors.

The study method consists of four stages with the main lines. These stages are as follows.

The literature review and data collection: At this stage, the data related to the gardens of public institutions and landscape design criteria in these gardens were collected in the context of the study subject.

The determination of the current situation in the study area (Findings): The photographs related to the garden of Konya Courthouse were taken during working hours in different weeks and on random days. The questions of the questionnaire were prepared accordingly.
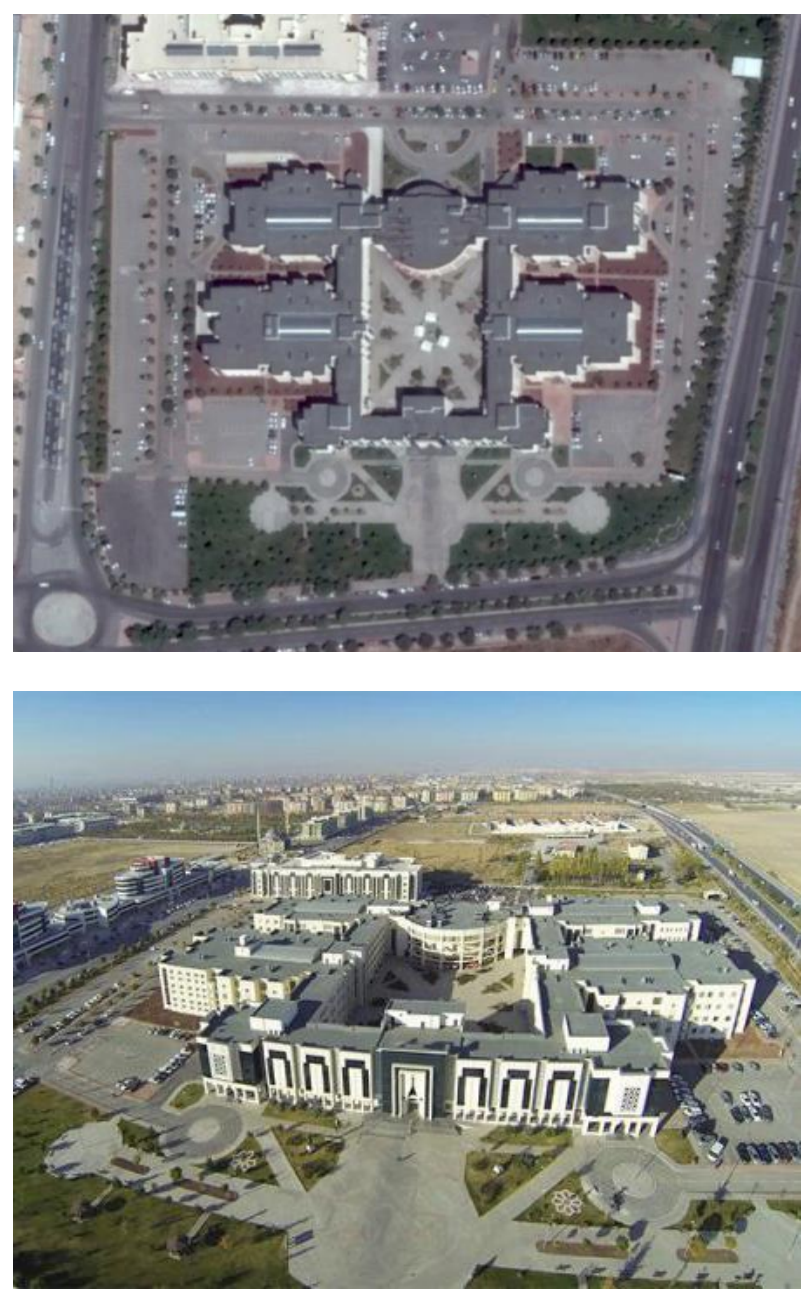

Figure 1 Google Earth and air image of the study area in 2016.

The questionnaire: The questionnaire about the landscape of the courthouse garden was applied to the court personnel (judges, prosecutors, lawyers, civil servants, police, etc.) using Konya Courthouse and the individuals having a lawsuit within the working hours in different weeks and on random days and their opinions were received. 
The official permission of the chief prosecutor of Konya province was obtained for these interviews. The questionnaire study continued for 1 week. The questionnaire was conducted with only 101 people since the study area was a courthouse and people were worried about time.

Making Suggestions: Design suggestions were made for the garden of the courthouse in accordance with the landscape architecture design criteria and the questionnaire study.

\section{Findings}

There are three different activities enabling people to be in public spaces. These are;

- Obligatory acts: Walking to work, paying debts

- Voluntary acts: Sitting, wandering

- Social acts: Meeting, gathering

With the interaction of these activities, a good city should keep people in public spaces in terms of design and provide a basis open to possibilities, new relationships, and surprises (Sinmaz 2015:68).

Design in urban spaces affects individuals socially, culturally, physically and psychologically. There are a certain number of principles to take into consideration since public spaces are a part of urban spaces (Sar1 2008:23). These are;

The principle of directing: The principle of directing in the urban space design is creating a corridor from spaces, in other words, developing the directing axis and transferring people from one place to another. The directing axis can be provided with different forms (Sar1 2008:23).

While the main entrance pedestrian directing is sufficient in Konya Courthouse, due to the fact that the parking area is at the back and there are not enough direction plates, users park on roads and tie traffic up.

Maintaining function-functionality: It is essential to functionalize urban space in accordance with the way of living of people in that region and the purpose to be carried out; therefore, urban spaces become public and survive. Moreover, it is important not to deviate from the aim of the space and not to mix its functions, otherwise, the functionality of the space will disappear (Sar1 2008:25).

Because of the threats to be mentioned in the conclusion, functionality is required in plantal and structural materials in the study area rather than security.

The usage of the objects (suitability and adaptation to the environment, situation): In the space design, the twodimensional texture and material of the urban space have different effects on the perception of the space. Moreover, the objects such as a column, statue, fountain, water, tree, etc. are the objects like architectural elements that can be frequently used to provide the organization of the space and create a common architectural language (Sar1 2008:27).
Some landscape objects such as pools had to be used differently from their usage areas because of the safety of children living in the houses close to the courthouse.

Ensuring the continuity of the circulation (series, rhythm, repetition): The principle of ensuring the continuity of the circulation of pedestrians and vehicles separately can be obtained from the opinion of "designing by creating a circulation network" supported by the relation theory. The solutions such as three-dimensional designing in places in which pedestrians and vehicles prevent each other's circulations can be searched by identifying the problems emerging in the current pedestrian-vehicle roads in the environment, in the entrance/exit places to the land from the environment and in the continuity of circulation (Sar1 2008:27).

Transportation becomes a problem from time to time because of the pedestrian density on juridical days which are Tuesday and Thursday. Pedestrian overpasses can be built for the safety of the students studying at the current schools across the courthouse.

For the landscape design of Konya Courthouse, it was aimed to design it both aesthetically and functionally according to the quality of the study area. Firstly, the current data of the area were evaluated in the design analysis.

The study area is positioned as a perfect square and located in the middle of a 4-storey courthouse area. The parking areas are located at the back of the courthouse, however, since there are no direction plates, it is hard to notice them.

There is a security at the first entrance to the area. The entrance is designed in accordance with the standards and controlled by the security unit. (Figure 2).

When proceeded directly from the entrance, there are direction plates for the access to the buildings in the courthouse campus area (Figure 3 ).

The entrance door of the building is located at the height of 1-5 $\mathrm{m}$ on the ground, and not only stairways at the entrances but also wheelchair ramps are used in accordance with the standards (Figure 4).

While the floor covering is mostly andesite, parquet keystones are used in the pavements (Figure 5).

There are deteriorations in some places on the floorings in the area and this situation prevents walking and causes a drainage problem (Figure 6). According to Rios et all. 2016, Pete V. Domenici U.S. Courthouse Landscape design achieves The U.S. General Services Administration (GSA)'s cost-saving sustainability goals in three interconnected ways: ecologically, economically, and culturally. In terms of ecology, the landscape design reintroduces native plants that require little supplemental irrigation, provides irrigation by collecting and re-using rainwater, filters stormwater runoff in on-site bioswales, decreases water usage by $85 \%$, and replaces broad areas of unnecessary pavement with shade to help reduce heat island effect. 


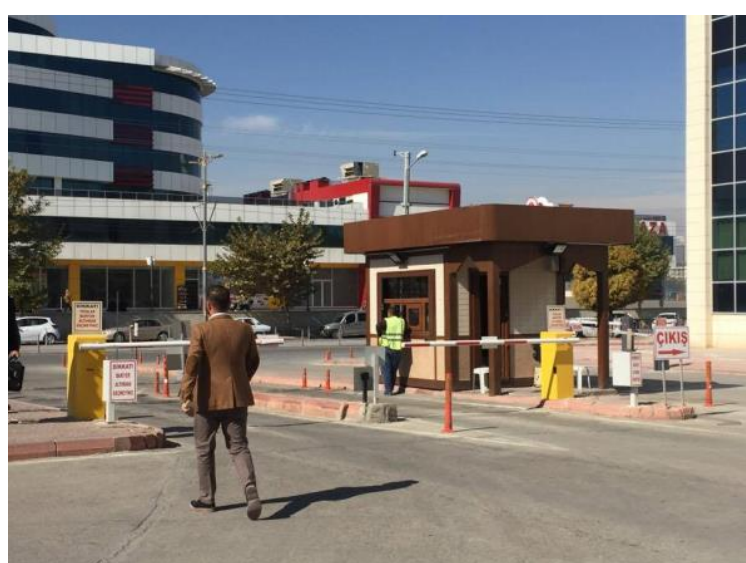

Figure 2 Entrance to the area and security (Original 2016)
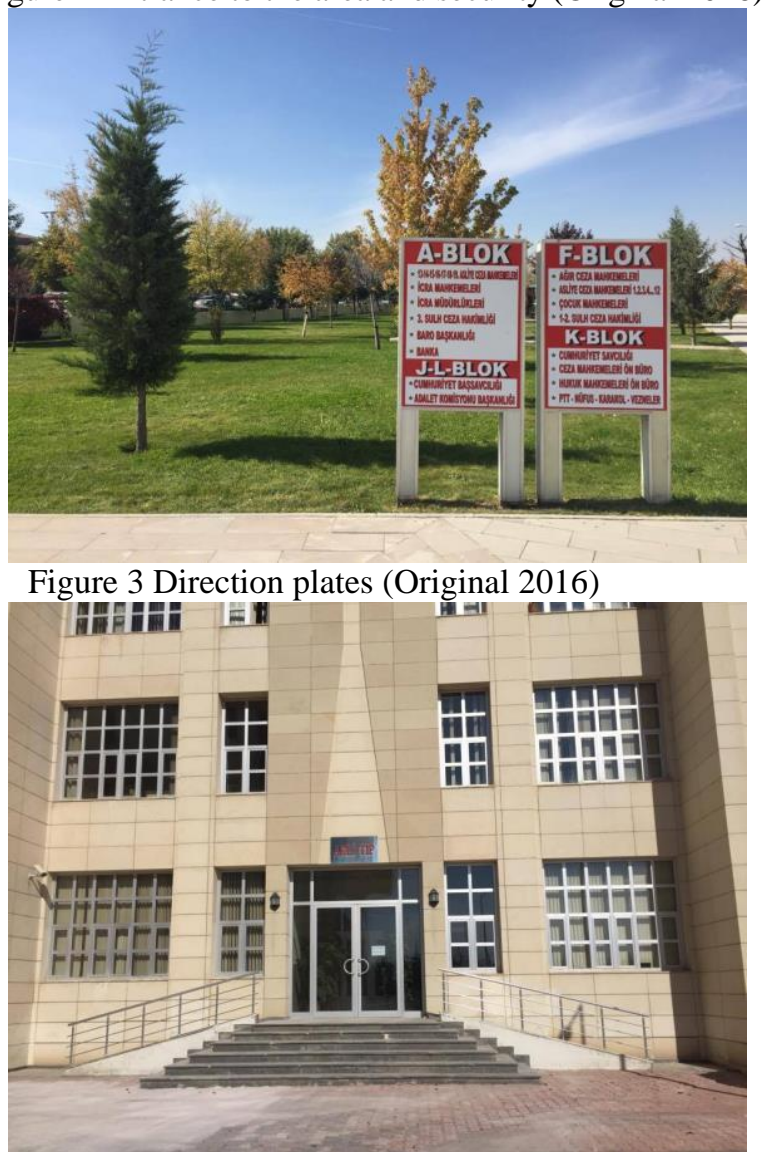

Figure 4 The stairways and disabled access ramps of the forensic entrance (Original 2016)

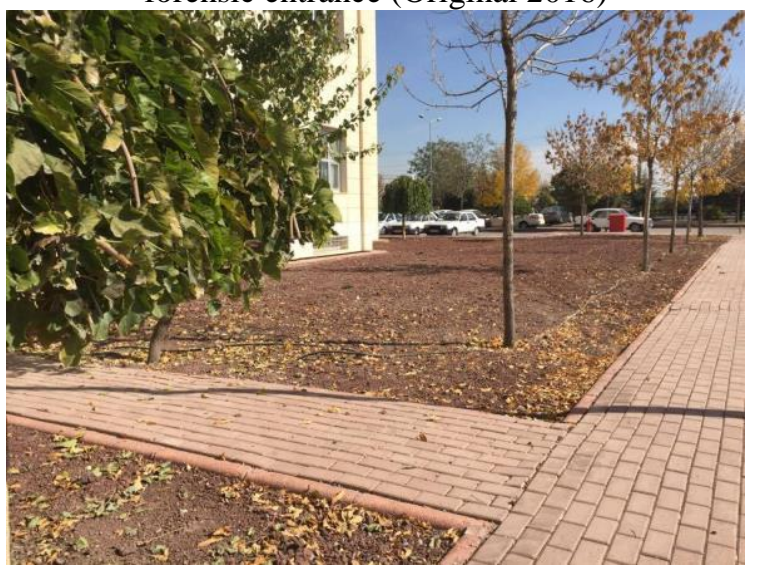

Figure 5 Floor coverings (Original 2016)
The area is completely floored with structural materials.

A number of green spaces, of which landscape design is performed, is not enough when compared to the general garden area.

While there are mostly sitting elements in the area, there are also enough equipment elements.

There is no water element in the area. There is a decorative pool in the central garden, however, it is filled with soil to eliminate the hazards that may occur since the children from the neighborhood enter the pool for fun. It was stated after the meeting conducted with the authorities that seasonal flowers would be planted in the decorative pool filled with soil (Figure 7).

The questionnaire study was conducted to identify the sufficiency and the usability of the courthouse garden and the findings acquired are as follows.

42 courthouse personnel, 27 lawyers and 32 individuals who came for a trial, 101 individuals in total, participated in the questionnaire study. The same questions about the courthouse garden were asked to all participants.

Some of these questions are of how much time the participants spend in the courthouse garden, how long they stay in the courthouse, the sufficiency of the size of the courthouse garden, the condition of the sufficiency of the sitting areas in the garden, the condition of noise in the courthouse garden and the level of its impact, the most and the least favorite places in the courthouse garden and the spaces which the participants want to add or remove personally.

According to the results of the questionnaire study, while $20 \%$ of the participants found the size of the courthouse garden completely sufficient, $64 \%$ found it partially sufficient. All of $16 \%(100 \%)$ who found the size of the garden insufficient are defendants, witnesses, complainants, etc. coming from outside. Thus, this indicates us the desire of people coming from outside for beautifully designed landscape areas to relax while waiting. Most of the courthouse personnel found the size of the garden sufficient.

While $70 \%$ of the participants found the sitting areas/elements in the courthouse garden sufficient, 30\% found them insufficient. The personnel can spend time outdoors only during the lunch break, however, people coming from outside spend most of their time in the central garden in which there are pergola areas and cafeterias.

When the question about the usage areas of the courthouse garden was asked to the citizens and employees who participated in the questionnaire, $71 \%$ stated that they do not use any area except for the parking area. A group of $10 \%$ stated that the garden has only meeting places during the lunch break and a group of $9 \%$ stated it is a resting area. It was identified that $3 \%$ use the garden just for its view. $7 \%$ stated they never use the garden.

The questions about the sufficient and insufficient areas in the courthouse garden were asked to the participants. In accordance with the answers, $63 \%$ found 
illumination elements sufficient, $8 \%$ found them insufficient and $29 \%$ found them partially sufficient.

$57 \%$ found dustbins in the area sufficient, $13 \%$ found them insufficient.

The banks and pergolas used by the personnel only during lunch breaks and by the people for waiting before/after the trial were found sufficient at the rate of $82 \%$ and insufficient at the rate of $12 \%$.

While $24 \%$ of the personnel found flower parterres in the garden sufficient, they were found insufficient at such a high rate as $70 \%$.

Since there is not a still or moving water surface in the area, $100 \%$ found this condition insufficient.

$20 \%$ found the usage of green spaces sufficient, $63 \%$ found it insufficient and $17 \%$ found it partially sufficient.

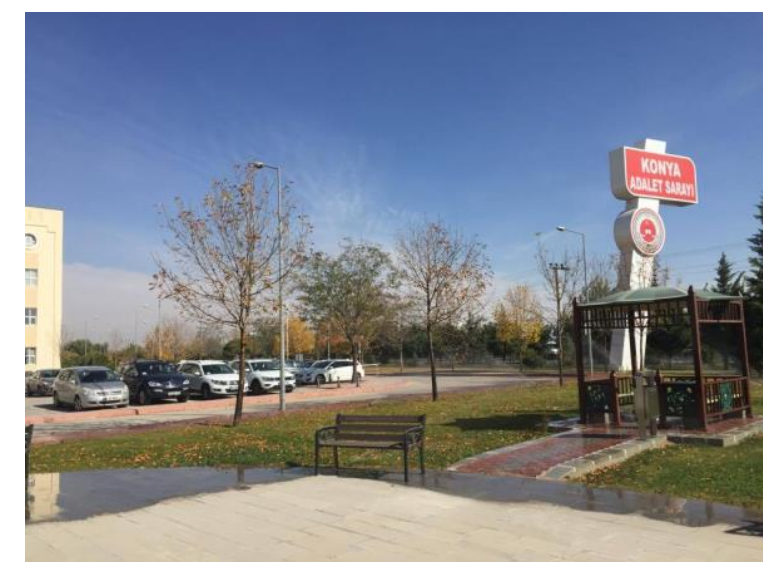

Figure 6. The flooring deterioration and drainage problem in the front garden (Original 2016)

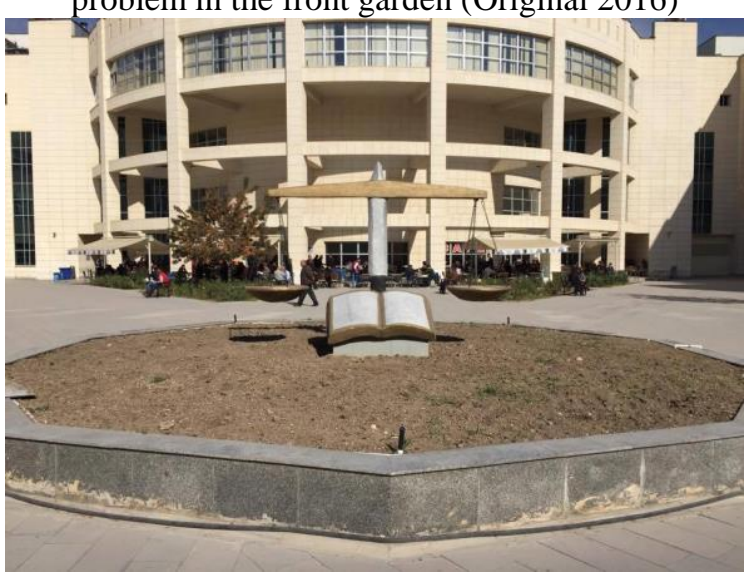

Figure 7. The decorative pool (filled with soil) located in the central garden of the courthouse (Original 2016)

\section{Conclusion and Suggestions}

Creating spaces suitable for use, aesthetic and accessible is among the main objectives of design studies. The fact that these studies are successful and sustainable is directly related to the requirements of users and their standards of living. Public spaces are also the part of the urban life like open green space systems and the users are highly important. However, each design has different characteristics since it is performed with different perspectives. It is quite difficult to meet in a common opinion in the areas offering the infinite number of options when the needs and requests are asked in areas addressing to the whole. The designer should evaluate what kind of units the public space will include and to whom it will address in the adaptation of the area to the environment to find a common ground for different perspectives.

Since the study area is the garden of Konya Courthouse, we encountered a very wide range of human profiles. Firstly, the needs of the courthouse personnel and then the needs of other user groups in the area were evaluated. The requests, needs, in other words, the requirements to increase the quality of life of not only the personnel but also of all individuals using that area were evaluated in the courthouse garden design and a study addressing the whole was conducted.

Gardens in public spaces are not the areas created to meet the needs of only the personnel such as relaxing, comforting and talking in the working tempo. Moreover, they are common areas used by all individuals in the society. The courthouse garden is the place used by defendants, witnesses, complainants, lawyers, judges, courthouse personnel and the relatives of these individuals in accordance with their jobs.

It is seen according to the results of the questionnaire study that the environmental design of Konya Courthouse lacks in terms of plantal landscape design criteria and is used wrongly. While the size of the courthouse garden is sufficient when compared to the courthouse gardens in other provinces, the insufficiency of the green spaces in the garden and the insufficiency of plant materials and urban furniture were identified as remarkable negative sides.

There is a need for adding sitting elements with shades, still and moving water surface, flower parterres, rock garden, garden of fragrant plants and trees and bushes with flowers and leaves changing colors for four seasons, which are new usages the deficiency of which we have determined, to make the courthouse garden more suitable in terms of the landscape design criteria and more aesthetic in terms of the visual quality.

It was found out in the verbal interview with the director of administrative services of the courthouse who is one of the participants of the questionnaire that although it is known that Morus nigra pendula in the courthouse garden admired by everyone are imperfect, they had to made prunning shapelessly to prevent the personnel working in the courthouse as workers because of "supervised liberty" and "good conduct" from hiding a knife or a weapon under the plant. The honorable director stated that 20 fruit tree saplings would be purchased for the courthouse garden in the shortest time and he would endeavor to make the environment more livable.

It is required to remove the confidential areas in the designs that can create a "threat", to prune the bushes without letting them to branch from the bottom, to avoid fully closed sitting areas, not to choose the flooring from easily removable materials and to completely immobilize the illumination elements to take care of the "safety" issue while designing public institutions in accordance with the current landscape design criteria. 


\section{References}

Atabeyoğlu Ö, Bulut Y. 2007a. Kamu Kurum ve Kuruluşları Dış Mekan Kalite Yeterliliklerinin Puanlama Yöntemi İle Değerlendirilmesi. Süleyman Demirel Üniversitesi Orman Fakültesi Dergisi Seri: A, Say1: 1, Y11: 2007, ISSN: 13027085, Sayfa: 92-106. Isparta.

Atabeyoğlu Ö, Bulut Y. 2007b. Kamu kurum ve kuruluşlarının dış mekan kullanım ve yeterliliğinin belirlenmesi üzerine bir araştırma. Ankara Üniversitesi Ziraat Fakültesi Tarım Bilimleri Dergisi 13(2): 89-94. Ankara.

Ayık C. 2011. Sürdürülebilir Kentsel Tasarım Kriterleri Çerçevesinde Geleneksel ve Çağdaş Şehirlerde (Ekoşehirler) Kamusal Mekanların Karşılaştırılması. İstanbul Teknik Üniversitesi, Fen Bilimleri Enstitüsü, Anabilim Dalı: Disiplinler aras1 Programı: Kentsel Tasarım. Sayfa sayıs1:101. İstanbul. https://polen.itu.edu.tr/bitstream/11527/2324/1/11509.pdf $(01 / 12 / 2016)$

Bayram B. 2007. Kamusal Mekan Kalitesinin Yükseltilmesinde Yöntemler ve Kamusal Sanatın Rolü. İ.T.Ü Fen Bilimleri Enstitüsü Yüksek Lisans Tezi, 169 sayfa ,İstanbul.

Kaplan H, Öztürk M. 2004. Engelliler, Kamu mekanı ve Engelsiz Tasarım: Kamusal İç Mekanlarda İrdelenmesi İçin Bir Çerçeve. TMMOB Şehir ve Bölge Planlama Odası Dergisi, Planlama http://www.spo.org.tr/resimler/ekler/290a7385ed77cc5_ek.p df $(01 / 12 / 2016)$

Sarı K. 2008. Kentsel Dış Mekan Tasarımına Kullanıcı Mekanlı Bir Yaklaşım. Süleyman Demirel Üniversitesi Fen Bilimleri Enstitüsü Şehir ve Bölge Planlama Anabilimdalı Yüksek Lisans Tezi. Isparta.
Topraklı YA, Adem A, Dağdeviren M. 2016. A Courthouse Site Selection Method Using Hesitant Fuzzy Linguistic Term Set: A Case Study For Turkey. ScienceDirect. Procedia Computer Science 102: $603-610$.

Turgut H. 2011. Erzurum Büyükşehir Belediye Binası Ön Bahçe Peyzaj Tasarım Çalışmasının Tasarım İlkeleri Bağlamında Değerlendirilmesi. Artvin Çoruh Üniversitesi Orman Fakültesi Dergisi 12(2):185-198.

Kavak M. 2010. Evrensel tasarım yaklaşımı bağlamında kamusal mekanlar: Harbiye Kongre Vadisi Örneği. Bahçeşehir Üniversitesi, Fen Bilimleri Enstitüsü, Kentsel Sistemler ve Ulaştırma Yönetimi, Yüksek Lisans Programı. İstanbul.

Rios M, Harris S, Tramutola M, Jacobsen B, Kantner A. 2016. Pete V. Domenici U.S. Courthouse Sustainable Landscape Retrofit. Albuquerque, NM. Web page: $\mathrm{http}: / /$ worldlandscapearchitect.com/pete-v-domenici-u-scourthouse-sustainable-landscape-retrofit-albuquerque-usarios-clementi-hale-studios/\#.WInLCHnau70 (01/02/2017)

Sirel A, Sirel Ü. 2005. Kamusal Dış Mekanlarının Tasarımında Aydınlatma Boyutu: "Edirne'de Hürriyet Meydanı (park1) İle İlgili Bir Araştırma" TMMOB Elektrik Mühendisleri Odas1. III. Ulusal Aydinlatma Sempozyumu. 23-25 Kasim 2005 Ankara. http://www.emo.org.tr/ekler/e2545f819e67f06_ek.pdf $(28 / 01 / 2017)$

Sınmaz S. 2015. Gelişen İletişim Teknolojilerinin Kentsel Yaşam ve Kamusal Mekânlar Üzerindeki Yansımaları. Tasarım+Kuram Dergisi. Cilt 11(20): 63-75. ISSN: 13022636. 